\title{
Correlating Field Symptoms of PNRSV with DAC and DAS-ELISA
} based Serological Detection

\author{
Shelly Kapoor and Anil Handa*
}

Plant Virology Laboratory, Department of Plant Pathology, Dr. Y S Parmar University of Horticulture and Forestry, Nauni - 173230, Solan, Himachal Pradesh, India

*Corresponding author

\section{A B S T R A C T}

\section{Keywords}

Field, PNRSV, DAC

DAS-ELISA, Serological Detection

Article Info

Accepted:

26 July 2018

Available Online:

10 August 2018
Field surveys were conducted between 2015-2018 to determine the occurrence and distribution of PNRSV infecting peach in 40 orchards representing major peach producing districts of Himachal Pradesh Symptomatic trees typical of viral infection present in all the orchards surveyed exhibited chlorotic spots, necrotic rings, leaf deformation and shot hole symptoms with an incidence ranging from 1 to 47 percent. DAC-ELISA confirmed the association of an Ilarvirus with peach cv. July Elberta infected plants and DAS-ELISA test further conclusively proved that the Ilarvirus associated with infected plants was PNRSV.

\section{Introduction}

India produces considerable quantity of all stone fruits including peach, plum, apricot and cherry. These are mainly grown in the NorthWestern Indian states of Jammu and Kashmir, Himachal Pradesh and Uttarakhand.

Besides, North-Eastern hilly region, comprising of the states of Arunachal Pradesh, Nagaland, Meghalaya, Manipur and Sikkim also grows stone fruits on a limited scale. Due to introduction and adaptation of low chilling cultivars, peach and plum are also now being grown commercially in certain areas of the north Indian plains. Among all stone fruits, peach is the most important in terms of production and area under cultivation.
Routine surveys conducted for recording the natural occurrence of virus diseases in different peach growing areas of Solan, Shimla, Sirmour and Kullu district of Himachal Pradesh revealed the presence of prunus necrotic ring spot disease with typical viral etiology. Prunus necrotic ring spot virus, is a member of the genus Ilarvirus belonging to the family Bromoviridae and thought to be transmitted by vegetative propagation. In India, natural occurrence of prunus necrotic ring spot disease was earlier confined to roses and cherries but it is now considered to be a serious emerging problem in the peaches and pose a threat to its cultivation in the state. Serological detection of a virus infecting peaches in Himachal Pradesh revealed the prevalence of PNRSV (Chandel et al., 2013; 
Kapoor and Handa 2017a). Serological and molecular methods of detection by employing enzyme-linked immunosorbent assay (ELISA) and reverse transcription polymerase chain reaction (RT-PCR) are widely used all over the world in different virus indexing and certification programmes of peach (Mink 1992). However, for virus indexing on mass scale, ELISA is widely employed because of its rapidity, accuracy and sensitivity.

\section{Survey}

Surveys were conducted during active growing seasons of 2015, 2016, 2017 and 2018 in different peach growing districts of Himachal Pradesh to record the occurrence, distribution and incidence of viral diseases in peach orchards situated at different locations. Percent disease incidence was calculated after recording observations on symptoms as per the formula given below:

Number of plants infected Disease incidence $(\%)=$----------------- x 100

Total number of plants

\section{Marking of symptomatic and disease free trees}

Peach trees existing in the surveyed orchards were critically observed for recording the symptoms on each cultivar. Symptomatic trees of different cultivars were marked for recording the observations on the symptoms as well as serological detection of viruses by following enzyme-linked immunosorbent assay (ELISA) technique. Alkaline phosphatase (ALP) based direct form of double antibody sandwich (DAS) ELISA was used to detect the infection of PNRSV by following Clark and Adam (1977). The procedures of detection are described in this chapter. Additionally, true to type, good quality, apparently healthy trees of peach cv. July Elberta were marked in the selected orchard for serological indexing by using ELISA.

\section{Serological detection of virus}

Leaf samples exhibiting typical symptoms were drawn from the marked plants in the selected orchard and brought to the laboratory in separate polythene bags in an ice box so as to keep the leaf samples fresh for serological detection of prunus necrotic ring spot virus (PNRSV) through Alkaline phosphatase (ALP) based DAC (direct antigen coating) and DAS (double antibody sandwich) forms of ELISA as per the procedure given below:

\section{Serological detection through DAC-ELISA}

ALP based DAC form of enzyme-linked immunosorbent assay (ELISA) was used to detect the viruses in test samples as per the protocol proposed by Handa and Bhardwaj (1994). Young leaves exhibiting typical viral symptoms were harvested and brought to the laboratory in polythene bags. Leaf extract of each sample in extraction buffer $(1: 20 \mathrm{w} / \mathrm{v})$ was prepared by crushing the leaves in a tissue homogenizer (SEDIAG, France) and used for coating the wells of microtitre ELISA plates. The wells of microtitre plate were filled with $200 \mu \mathrm{l}$ aliquots of test sample. The coated plates were kept in a humid box and incubated overnight at $4 \pm 1{ }^{0} \mathrm{C}$. The plates were washed by removing suspension of samples by vigorously shaking out the plate over the wash basin. The wells were filled with $1 \mathrm{X}$ PBSTween and kept for 2 minutes with gentle shaking and emptied the plate and in this way the washing was repeated 3 times or simply by washing in ELISA plate washer. Then the wells were filled with $200 \mu \mathrm{l}$ aliquots of coating antibodies diluted in $1 \mathrm{X}$ coating buffer. The plate was incubated in humid box for 2 hours at $37^{\circ} \mathrm{C}$ the washing of the plates was done as mentioned before. ALP labeled goat anti-rabbit IgG conjugate (GeNei, 
Bangalore) were filled in each well with 200 $\mu \mathrm{l}$ aliquots after diluting in $1 \mathrm{X}$ conjugate buffer. The plate was incubated in a humid box for 2 hours at $37^{\circ} \mathrm{C}$. The washing of plate was done as mentioned previously. The pNPP substrate was dissolved in $1 \mathrm{X}$ substrate buffer (5 mg pNPP tablet in $5 \mathrm{ml}$ of substrate buffer) under dark conditions. Each well was filled with $200 \mu \mathrm{l}$ aliquots of substrate. The plate was kept in humid box in dark at room temperature. The plate was incubated until a yellow colour was visible in the positive controls (usually between 30 and 90 minutes). If desired, the reaction was stopped by adding $50 \mu \mathrm{l}$ of $3 \mathrm{M} \mathrm{NaOH}$ to each well. The results were assessed by measurement of the absorbance value of the hydrolysed substrate (p-nitrophenyl) at $405 \mathrm{~nm}$ wavelength in a microtitre plate reader (Micro Scan MS5605A, Electronic Corporation of India Limited).

Leaf samples from fifty symptomatic trees were collected from the selected orchard surveyed in the experimental farm of the Departments of Fruit Science of Dr YS Parmar University Nauni, Solan for serological detection of two ilarviruses namely apple mosaic virus (ApMV) and prunus necrotic ring spot virus (PNRSV) through DAC-ELISA since these two viruses have been reported to be associated with stone fruits in India. For all serological tests of ELISA, immunoreagents, buffers, positive and negative control supplied by BIOREBA AG (Switzerland) were used as per the instructions issued by the supplier.

\section{Serological detection through DAS-ELISA}

Alkaline phosphatase based direct double antibody sandwich enzyme-linked immunosorbent assay (ELISA) was used to detect the virus as per the protocol of Clark and Adams (1977) with slight modifications. The detailed procedure used for DAS-ELISA based serological detection of PNRSV is described hereunder: In DAS-ELISA, wells of the microtitre plate except those of the top and bottom rows on the extreme left and right were first filled with $200 \mu \mathrm{l}$ coating antibody. The plate was incubated in humid box for 4 hours at $30{ }^{0} \mathrm{C}$. The coating antibody suspension was removed by vigorously shaking out the plate over the wash-basin. The wells were filled with $1 \mathrm{X}$ PBS-Tween and kept for 2 min with gentle shaking emptied the plate and filled again with PBS-Tween. The washing was repeated three times or by washing in ELISA plate washer. The leaf extract from the test samples were prepared in buffer. All coated wells were filled with 200 $\mu l$ aliquots of test samples (each sample at least in duplicate) besides positive control and negative control wells. The plates were incubated in humid box overnight at $4 \pm 1^{0} \mathrm{C}$. The washing step was repeated as mentioned above.

The specific alkaline phosphatase (ALP) based conjugated antibodies were filled in each well with $200 \mu \mathrm{l}$ aliquots. The plate was incubated in humid box for 5 hours at $30^{\circ} \mathrm{C}$. The washing was done as mentioned above. The p-nitrophenyl phosphate (pNPP) substrate was dissolved in $1 \mathrm{X}$ substrate buffer by dissolving $5 \mathrm{mg}$ pNPP tablet in $5 \mathrm{ml}$ of $1 \mathrm{X}$ substrate buffer under the dark conditions. Each well was filled with $200 \mu \mathrm{l}$ aliquots of substrate. The plates were kept in humid box in the dark condition at room temperature after giving a brief incubation of 15 minutes at $30^{\circ} \mathrm{C}$. The plates were incubated until a yellow colour was clearly visible in the positive controls (usually between 30 and 90 minutes). If desired the reaction was stopped by adding $50 \mu \mathrm{l}$ of $3 \mathrm{M} \mathrm{NaOH}$ to each well. The results were assessed either by measurement of the absorbance value of the hydrolyzed substrate (p-nitrophenyl) at $405 \mathrm{~nm}$ wavelength in a microtitre/(ELISA) plate reader (Micro Scan MS5605A, Electronic Corporation of India Limited) or through visual screening. 
Leaf samples from twenty symptomatic trees which were found positive in DAC-ELISA were collected for further serological detection through DAS-ELISA in selected orchard surveyed in the experimental farm of the Departments of Fruit Science, Dr YS Parmar University Nauni, Solan. For all serological tests of ELISA, immunoreagents, buffers, positive and negative control supplied by BIOREBA AG (Switzerland) were used as per the instructions issued by the supplier. The results in both DAC and DAS forms of ELISA for detection of PNRSV were interpreted by following Lemmetty (1988) and Dijkstra and Jager (1998) as samples were considered infected when their OD values at $405 \mathrm{~nm}$ exceeded two times the mean values of respective healthy and negative control samples.

Occurrence, distribution and incidence of viral diseases in major peach growing districts of Himachal Pradesh

Field surveys were conducted between 20152018 to determine the occurrence and distribution of PNRSV infecting peach in 40 orchards representing major peach producing districts of Himachal Pradesh (Table 1). Observations on incidence recorded are presented in (Table 2a, b. c and d). Owing to its latent nature, symptoms of PNRSV are largely masked.

Some of the typical symptoms were however recorded during specific period of the year on major cultivars like July Elberta, Glo Haven and Sun Haven growing in several orchards in Solan, Sirmour, Shimla and Kullu districts. Predominant symptoms prevalent in most of the cultivars observed were leaf damage in the form of mosaic, chlorotic spots, necrotic rings, shot holes, mid vein distortion and oak leaf pattern on leaves (Plate I). Such type of symptoms have been reported to be associated with peach trees infected with PNRSV by a number of workers (Fulton 1970; Wells et al., 1986; Brunt et al., 1996; Hammond 2011; Almaraz et al., 2014; Winkowska et al., 2016; Kapoor and Handa 2017a).

Data presented in Table 2 (a, b, c and d) clearly indicate the prevalence of PNRSV infection in all the orchards surveyed with an incidence ranging from 2 to 17 percent in Shimla district, 5 to 18 percent in Kullu district, 4 to 28 percent in Solan district and 5 to 37 percent in Sirmour district of Himachal Pradesh. In Shimla district, maximum incidence of PNRSV was recorded at NBPGR Phagli (17 percent) followed by IARI regional station Dhanda with an incidence of 15 percent whereas minimum incidence of 2 percent was recorded at Dhami.

In Kullu district, maximum incidence of PNRSV was recorded at Manali (18 percent) followed by Seo Bagh (15 percent) and Sharabhai recorded the minimum disease incidence (5 percent). Maximum incidence was recorded at Patta Mehlog (28 percent) in Solan district which was followed by Deothi with an incidence of (15 percent) and Kuthar had minimum incidence of 4 percent. In Sirmour district, maximum incidence of 37 percent was recorded at Sanaura followed by Ratoli (23 percent) whereas Phagu recorded minimum incidence of 5 percent.

Recent studies conducted in different parts of the world on incidence levels of PNRSV revealed a huge variation. Incidence of PNRSV was reported to be 60 percent in Georgia (Wells et al.,1986); 25 percent in Turkey (Gumus et al., 2007); 70 and 100 percent in South Carolina (Scott 2014); 30 percent in Canada (Pallas et al., 2012); 25 percent in Mexico (Almaraz 2008); 32 percent in Saudi Arabia (Alhudaib and Rezk 2011); 15 percent in Central Bohemia, Czech Republic (Winkowska et al., 2016) and 18 percent in India (Kapoor and Handa 2017a). 
Plate.1 Symptoms of PNRSV on peach cv. July Elberta leaves

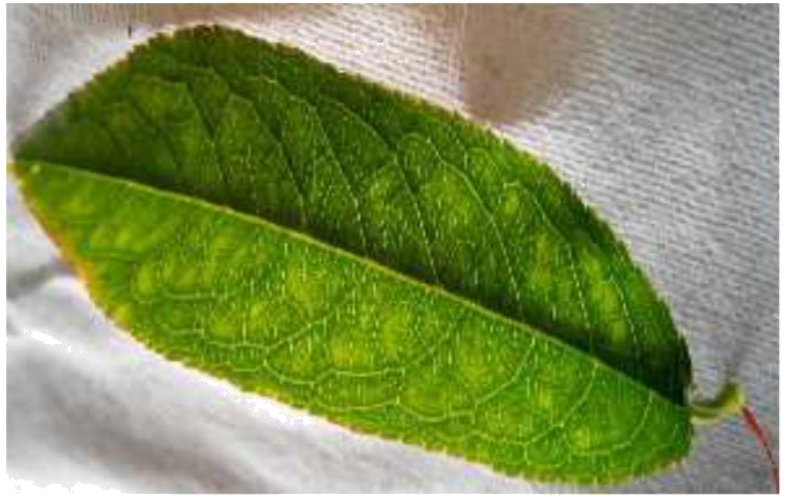

Diffused chlorotic spots

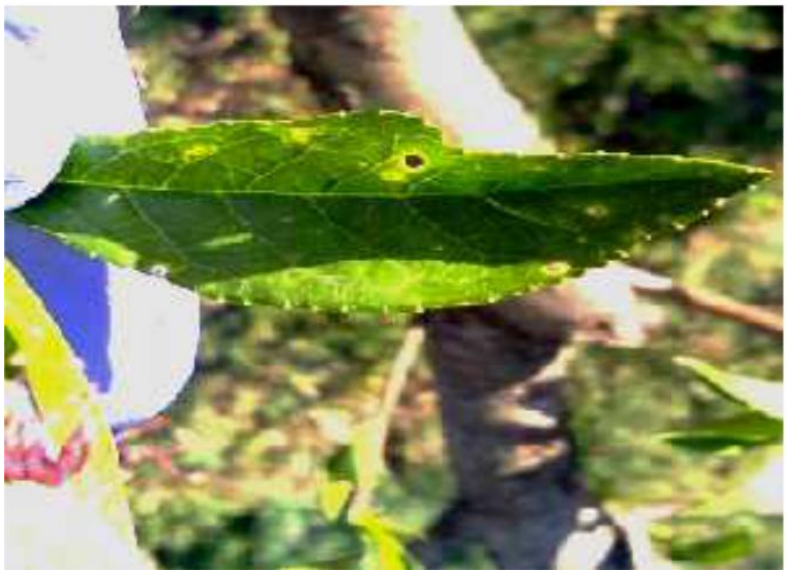

Necrotic rings

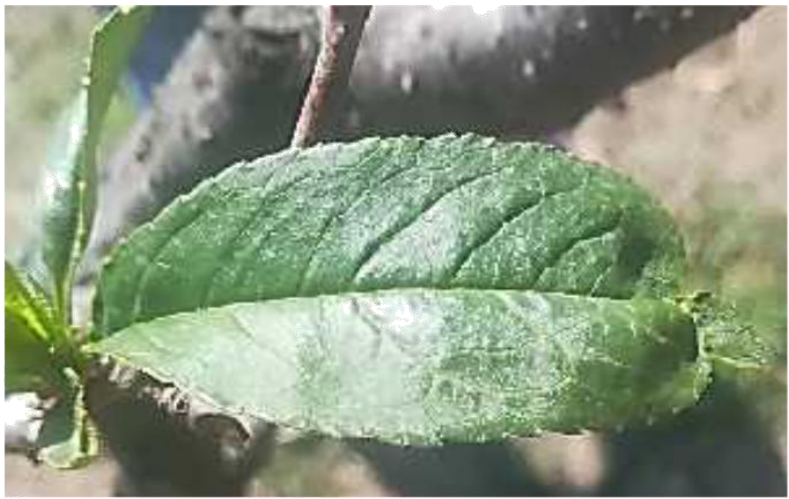

Deformed leaves



Oak leaf pattern



Mid vein distortion 
Table.1 Different peach growing areas selected for survey

\begin{tabular}{|l|l|}
\hline District & Area \\
\hline Shimla & $\begin{array}{l}\text { IARI regional station Dhanda, NBPGR Phagli, Suni, Basantpur, } \\
\text { Dhami, Shoghi, Jathiya Devi, Pujarli, Fagu, Gumma }\end{array}$ \\
\hline Kullu & $\begin{array}{l}\text { Bajaura, Seo Bagh, Manali, Panarsa, Gadsa, Sainj Valley, } \\
\text { Sharabhai, Jhiri, Shamshi, Raison }\end{array}$ \\
\hline Solan & $\begin{array}{l}\text { Dr YS Parmar University Nauni, Deothi, HRTS \& KVK } \\
\text { Kandaghat, Jatoli, Kuthar, Patta Mehlog, Sadhupul, Sabathu, } \\
\text { Jaunaji, Chail }\end{array}$ \\
\hline Sirmour & $\begin{array}{l}\text { Pabyana, Habban, Kotli, Ratoli, PCDO Gauda, Sanaura, Bhanat, } \\
\text { Phagu, Shannaghat, Kwagdhar }\end{array}$ \\
\hline
\end{tabular}

Table.2a Incidence of PNRSV on peach trees in different orchards of Shimla district

\begin{tabular}{|c|l|c|}
\hline Orchard No. & Location & Incidence (\%) \\
\hline Orchard-1 & IARI regional station Dhanda & 15 \\
\hline Orchard-2 & NBPGR Phagli & 17 \\
\hline Orchard-3 & Suni & 09 \\
\hline Orchard-4 & Basantpur & 05 \\
\hline Orchard-5 & Dhami & 02 \\
\hline Orchard-6 & Shoghi & 11 \\
\hline Orchard-7 & Jathiya Devi & 04 \\
\hline Orchard-8 & Pujarli & 10 \\
\hline Orchard-9 & Fagu & 12 \\
\hline Orchard-10 & Gumma & 04 \\
\hline
\end{tabular}

Table.2b Incidence of PNRSV on peach trees in different orchards of Kullu district

\begin{tabular}{|c|l|c|}
\hline Orchard No. & Location & Incidence (\%) \\
\hline Orchard-1 & Bajaura & 12 \\
\hline Orchard-2 & Seo Bagh & 15 \\
\hline Orchard-3 & Manali & 18 \\
\hline Orchard-4 & Panarsa & 10 \\
\hline Orchard-5 & Gadsa & 07 \\
\hline Orchard-6 & Sainj Valley & 11 \\
\hline Orchard-7 & Sharabhai & 05 \\
\hline Orchard-8 & Jhiri & 10 \\
\hline Orchard-9 & Shamshi & 07 \\
\hline Orchard-10 & Raison & 11 \\
\hline
\end{tabular}


Table.2c Incidence of PNRSV on peach trees in different orchards of Solan district

\begin{tabular}{|c|l|c|}
\hline $\begin{array}{c}\text { Orchard No. } \\
\text { Orchard-1 }\end{array}$ & Location & Incidence (\%) \\
\hline Orchard-2 & Deothi & 13 \\
\hline Orchard-3 & HRTS \& KVK Kandaghat & 08 \\
\hline Orchard-4 & Jatoli & 05 \\
\hline Orchard-5 & Jaunaji & 10 \\
\hline Orchard-6 & Kuthar & 04 \\
\hline Orchard-7 & Patta Mehlog & 28 \\
\hline Orchard-8 & Sadhupul & 10 \\
\hline & & 06 \\
\hline Orchard-9 & Sabathu & 11 \\
\hline Orchard-10 & Chail & \\
\hline & & \\
\hline
\end{tabular}

Table.2d Incidence of PNRSV on peach trees in different orchards of Sirmour district

\begin{tabular}{|c|l|c|}
\hline Orchard No. & Location & Incidence (\%) \\
\hline $\begin{array}{c}\text { Orchard-1 } \\
\text { Orchard-2 }\end{array}$ & $\begin{array}{l}\text { Pabyana } \\
\text { Habban }\end{array}$ & 11 \\
\hline Orchard-3 & Kotli & 07 \\
\hline Orchard-4 & Ratoli & 23 \\
\hline Orchard-5 & PCDO Gauda \\
\hline Orchard-6 & Sanaura & 17 \\
\hline Orchard-7 & Bhanat & 37 \\
\hline Orchard-8 & Phagu & 14 \\
\hline Orchard-9 & Shanaghat & 05 \\
\hline Orchard-10 & Kwagdhar & 11 \\
\hline
\end{tabular}


Table.3 Serological detection of Ilarviruses (PNRSV or ApMV) in the selected orchard through DAC-ELISA

\begin{tabular}{|c|c|c|c|}
\hline \multirow{3}{*}{$\begin{array}{l}\text { Tree } \\
\text { No. }\end{array}$} & \multirow[t]{3}{*}{ Symptoms } & \multicolumn{2}{|c|}{ OD Value $\left(\mathbf{A}_{405} \mathbf{n m}\right) /$} \\
\hline & & \multicolumn{2}{|c|}{ (Serological Reaction) } \\
\hline & & PNRSV & ApMV \\
\hline 1 & Mosaic, chlorotic spots & $0.102(-)$ & $0.009(-)$ \\
\hline 2 & Mosaic, necrotic rings, shot hole & $0.333(+)$ & $0.267(+)$ \\
\hline 3 & Mosaic, mid vein distortion & $0.008(-)$ & $0.123(-)$ \\
\hline 4 & Chlorotic spots, mid vein distortion & $0.144(-)$ & $0.156(-)$ \\
\hline 5 & Mosaic, necrotic rings, shot hole, oak leaf pattern & $0.356(+)$ & $0.265(+)$ \\
\hline 6 & Mid vein distortion & $0.036(-)$ & $0.020(-)$ \\
\hline 7 & Chlorotic spots, mid vein distortion & $0.045(-)$ & $0.097(-)$ \\
\hline 8 & Mosaic, necrotic rings, shot hole & $0.445(+)$ & $0.319(+)$ \\
\hline 9 & Chlorotic spots, mid vein distortion, necrotic rings & $0.367(+)$ & $0.266(+)$ \\
\hline 10 & Mosaic, chlorotic spots & $0.044(-)$ & $0.038(-)$ \\
\hline 11 & Mosaic, necrotic rings, shot hole & $0.377(+)$ & $0.236(+)$ \\
\hline 12 & Chlorotic spots, mosaic, mid vein distortion & $0.099(-)$ & $0.077(-)$ \\
\hline 13 & Mosaic, chlorotic spots, oak leaf pattern & $0.353(+)$ & $0.256(+)$ \\
\hline 14 & Mid vein distortion, mosaic & $0.056(-)$ & $0.087(-)$ \\
\hline 15 & Mosaic, chlorotic spots, necrotic rings & $0.279(+)$ & $0.234(+)$ \\
\hline 16 & Chlorotic spots & $0.061(-)$ & $0.054(-)$ \\
\hline 17 & Mosaic, mid vein distortion & $0.178(-)$ & $0.163(-)$ \\
\hline 18 & Chlorotic spots, necrotic rings & $0.301(+)$ & $0.259(+)$ \\
\hline 19 & Chlorotic spots, mid vein distortion & $0.126(-)$ & $0.132(-)$ \\
\hline 20 & Mosaic, mid vein distortion & $0.093(-)$ & $0.075(-)$ \\
\hline \multirow[t]{2}{*}{21} & Mosaic, chlorotic spots, necrotic rings, mid vein & $0.323(+)$ & $0.267(+)$ \\
\hline & Distortion & & \\
\hline 22 & Chlorotic spots, mid vein distortion & $0.045(-)$ & $0.064(-)$ \\
\hline 23 & Mosaic, necrotic rings & $0.146(-)$ & $0.137(-)$ \\
\hline 24 & Mosaic, necrotic rings, oak leaf pattern & $0.280(+)$ & $0.258(+)$ \\
\hline 25 & Mosaic, chlorotic & $0.068(-)$ & $0.074(-)$ \\
\hline 26 & Mosaic, necrotic rings, mid vein distortion & $0.308(+)$ & $0.251(+)$ \\
\hline 27 & Chlorotic spots, necrotic rings & $0.280(+)$ & $0.209(+)$ \\
\hline 28 & Mosaic, mid vein distortion & $0.124(-)$ & $0.098(-)$ \\
\hline 29 & Mid vein distortion, chlorotic spots & $0.142(-)$ & $0.128(-)$ \\
\hline 30 & Chlorotic spots, mid vein distortion & $0.106(-)$ & $0.115(-)$ \\
\hline \multirow[t]{2}{*}{31} & Mosaic, mid vein distortion, necrotic rings, oak leaf & $0.278(+)$ & $0.234(+)$ \\
\hline & Pattern & & \\
\hline 32 & Mid vein distortion & $0.053(-)$ & $0.065(-)$ \\
\hline 33 & Mosaic, chlorotic spots, mid vein distortion & $0.098(-)$ & $0.049(-)$ \\
\hline \multirow[t]{2}{*}{34} & Chlorotic spots, necrotic rings, oak leaf pattern, mid & $0.297(+)$ & $0.269(+)$ \\
\hline & vein distortion & & \\
\hline 35 & Mosaic, chlorotic spots, necrotic rings & $0.105(-)$ & $0.089(-)$ \\
\hline 36 & Mosaic, shot hole, necrotic rings, oak leaf pattern, mid & $0.333(+)$ & $0.287(+)$ \\
\hline
\end{tabular}




\begin{tabular}{|r|l|l|l|}
\hline & vein distortion & & \\
\hline 37 & Chlorotic spots, mosaic, mid vein distortion & $0.109(-)$ & $0.112(-)$ \\
\hline 38 & Mosaic, mid vein distortion & $0.067(-)$ & $0.100(-)$ \\
\hline 39 & Chlorotic spots, shot hole, oak leaf pattern, mid vein & $0.290(+)$ & $0.258(+)$ \\
\hline & Distortion & & \\
\hline 40 & Necrotic rings, chlorotic spots & $0.103(-)$ & $0.068(-)$ \\
\hline 41 & Mosaic, necrotic rings, chlorotic spots & $0.114(-)$ & $0.126(-)$ \\
\hline 42 & Mosaic, chlorotic spots, shot hole, mid vein distortion & $0.312(+)$ & $0.276(+)$ \\
\hline 43 & Necrotic rings, mid vein distortion & $0.095(-)$ & $0.076(-)$ \\
\hline 44 & Mid vein distortion, chlorotic spots & $0.116(-)$ & $0.104(-)$ \\
\hline 45 & Chlorotic spots, necrotic rings, mid vein distortion & $0.290(+)$ & $0.257(-)$ \\
\hline 46 & Chlorotic spots, necrotic rings, mid vein distortion & $0.278(+)$ & $0.289(+)$ \\
\hline 47 & Chlorotic spots, necrotic rings & $0.126(-)$ & $0.134(-)$ \\
\hline 48 & Mid vein distortion & $0.067(-)$ & $0.059(-)$ \\
\hline 49 & Necrotic rings, oak leaf pattern, mid vein distortion & $0.299(+)$ & $0.301(+)$ \\
\hline 50 & Mosaic, mid vein distortion & $0.097(-)$ & $0.065(-)$ \\
\hline
\end{tabular}

Table.4 Serological detection of PNRSV and ApMV in the selected orchard through DAS-ELISA

\begin{tabular}{|c|l|l|l|}
\hline Tree & Symptoms & \multicolumn{2}{|l|}{ O.D. Value A405nm } \\
\hline No. & & PNRSV & ApMV \\
\hline & & & \\
\hline 1 & Necrotic rings, oak leaf pattern & $0.345(+)$ & $0.102(-)$ \\
\hline 2 & Chlorotic spots, necrotic rings & $0.321(+)$ & $0.068(-)$ \\
\hline 3 & Shot hole & $0.467(+)$ & $0.112(-)$ \\
\hline 4 & Necrotic rings, shot hole & $0.328(+)$ & $0.079(-)$ \\
\hline 5 & Shot hole, necrotic rings, chlorotic spots & $0.279(+)$ & $0.057(-)$ \\
\hline 6 & Shot holes, oak leaf pattern, mid vein distortion & $0.378(+)$ & $0.146(-)$ \\
\hline 7 & Necrotic rings, shot hole, mid vein distortion & $0.296(+)$ & $0.131(-)$ \\
\hline 8 & Mosaic, mid vein distortion & $0.304(+)$ & $0.115(-)$ \\
\hline 9 & Chlorotic spots, necrotic rings, shot hole & $0.386(+)$ & $0.102(-)$ \\
\hline 10 & Chlorotic spots, shot hole & $0.265(+)$ & $0.098(-)$ \\
\hline 11 & Mosaic, necrotic rings, mid vein distortion & $0.411(+)$ & $0.056(-)$ \\
\hline 12 & Chlorotic spots, mid vein distortion & $0.260(+)$ & $0.109(-)$ \\
\hline 13 & Chlorotic spots, necrotic rings, mid vein distortion & $0.312(+)$ & $0.089(-)$ \\
\hline 14 & Chlorotic spots, necrotic rings & $0.294(+)$ & $0.111(-)$ \\
\hline 15 & Chlorotic spots, shot hole & $0.285(+)$ & $0.102(-)$ \\
\hline 16 & Shot hole, oak leaf pattern, mid vein distortion & $0.342(+)$ & $0.076(-)$ \\
\hline 17 & Necrotic rings, shot hole & $0.279(+)$ & $0.132(-)$ \\
\hline 18 & Chlorotic spots, shot hole, mid vein distortion & $0.342(+)$ & $0.126(-)$ \\
\hline 19 & Necrotic rings, mid vein distortion & $0.299(+)$ & $0.094(-)$ \\
\hline 20 & Chlorotic spots, shot hole, mid vein distortion & $0.345(+)$ & $0.106(-)$ \\
\hline & & & \\
\hline
\end{tabular}




\section{Selection of orchard}

Peach orchard located in the Experimental Farm of the department of Fruit Science, Dr YS Parmar University Nauni was selected for conducting the present studies. The orchard had young plants in the age group of 5-8 years and had only one variety of peach (July Elberta). The orchard was easily accessible from the laboratory which was favourable from the point of collecting samples and bringing them to the laboratory for further studies without causing any degradation of the samples, a major concern for PNRSV as the virus is a thermos-labile latent virus.

\section{Serological detection of PNRSV}

Leaf samples from the marked trees exhibiting typical viral symptoms in the selected orchard were collected and brought to the laboratory in separate polythene bags in an ice box. These samples were further serologically detected for the presence or absence of ilarviruses (PNRSV or ApMV) through the use of DAC-ELISA. Further confirmation of the exact identity of the virus was established through DAS-ELISA. The results pertaining to serological detection are presented in Tables 3 and 4.

\section{Serological detection of ilarviruses in the selected orchard through DAC-ELISA}

Alkaline phosphatase based DAC-ELISA was performed to detect the presence of ilarviruses (PNRSV or ApMV) in the leaf samples drawn from 50 symptomatic trees marked in the selected orchard. The data on OD values and serological reactions set out in Table 3 clearly indicate the positive detection of both ilarviruses in test samples. Positive samples had OD values that were at least double the OD value of negative control. ELISA plate depicting serological reaction of the virus isolates against ilarviruses in DAC-ELISA is presented in Plate II. DAC-ELISA results confirmed the presence of Ilarvirus in the orchard surveyed. However, OD values of the samples in respect of PNRSV was higher than that of ApMV. Therefore, further investigations were carried out using DASELISA to confirm whether PNRSV was present alone or in combination with ApMV as mixed infection.

Data presented in Table 3 on the basis of OD values clearly indicate the presence of ilarviruses (PNRSV and ApMV) as some of the samples reacted positively for both PNRSV and ApMV in DAC-ELISA. Out of 50 symptomatic trees, only 20 were found to be infected with ilarviruses as indicated by the OD values. Tree No. 8 recorded the maximum OD values of 0.445 followed by Tree No. 11 and 9 with OD values of 0.377 and 0.367 , respectively for PNRSV whereas in case of ApMV, Tree No. 8 recorded maximum OD value of 0.319 followed by Tree No. 49 and 46 with OD values of 0.301 and 0.289 , respectively. DAC-ELISA has been used widely for the detection of plant viruses (Ramiah et al., 2001; Sujitha et al., 2015; Rageshwari et al., 2017). Successful detection of ilarviruses under present studies is in conformity with the findings of Roussel et al., (2004) and Salem et al., (2004) who have also used DAC-ELISA for the detection of ilarviruses in temperate fruits. Besides, a number of other workers have also reported the association of ilarviruses with stone fruits on the basis of DAC-ELISA tests (Digiaro et al., 1991; Mink 1992; Hammond 2003; Bashir et al., 2017).

\section{Serological detection of PNRSV and ApMV in the selected orchard through DAS- ELISA}

Alkaline phosphatase based DAS-ELISA was performed for the detection of PNRSV and ApMV in the leaf samples drawn from 20 
symptomatic trees marked in the selected orchard and confirmed positive in DACELISA test. Observations recorded on OD values are presented in the Table 4.

It is evident from the data in Table 4 and Plate III that the Ilarvirus associated with test samples is PNRSV and not ApMV as leaf samples from all 20 symptomatic marked trees reacted positively with antibodies against PNRSV and failed to record positive reaction with antibodies against ApMV. Tree number 3 recorded the maximum OD value of 0.467 followed by tree number 11 and tree number 9 with OD values of 0.411 and 0.386 , respectively.

Use of DAS-ELISA for detecting viruses in peach is widely practiced and findings of the present studies are in line with those of a number of workers who have observed DASELISA to be an effective technique for detecting PNRSV in peach (Ghanem 2000; Myrtra et al., 2001; Salem et al., 2003; Virscerk and Mavric 2005; Syzndel et al., 2006; Salam et al., 2007; Almaraz et al., 2008; Chandel et al., 2013; Vemulapati et al., 2014; Kapoor and Handa 2017 a and b). The present studies have helped in correlating field symptoms of PNRSV with spectrophotometry based results obtained in DAC and DAS forms of ELISA and the finding can be very useful in linking field studies with ELISA tests.

\section{References}

Alhudaib K and Rezk A. 2011. Prunus necrotic ringspot virus in apricot (Prunus armeniaca) and peach ( $P$. persica) newly reported in Saudi Arabia. New Disease Reports 23: 26p.

Almaraz TD, Sanchez-Navarro J and Pallas V. 2014. Detection of Prunus necrotic ringspot virus in peach (Prunus persica L.) in Mexico and molecular characterization of its RNA component3. Agrociencia 48:583-598.

Almaraz Torre DL, Montoya-Piña JV, Rangel AS, Camarena-Gutiérrez G and SalazarSegura M. 2008. First Report of Prunus necrotic ringspot virus in Peach in Mexico. Plant Disease 92:482-482.

Bashir NS, Kashika M, Koolivand D and Eini O. 2017. Detection and phylogenetic analysis of prunus necrotic ringspot virus isolates from stone fruits in Iran. Journal of Plant Pathology 99: 114122.

Brunt AA, Crabtree K, Dallwitz MJ, Gibbs AJ, Watson L and Zurcher EJ. 1996. Apple mosaic Ilarvirus. Plant Viruses Online: Descriptions and Lists from the VIDE Database.

Chandel V, Rana T and Hallan V. 2013. Prunus necrotic ringspot virus: Incidence on stone and pome fruits and diversity analysis. Archives of Phytopathology and Plant Protection 46: 2376-2386.

Clark MF and Adams AN. 1977. Characteristics of the microplate method of enzyme-linked immunosorbent assay for the detection of plant viruses. Journal of General Virology 34: 475-483.

Digiaro M, Terlizi D and Savrino V. 1991. Ilarviruses in apricot and plum pollen. Acta Horticulturae 309: 93-98.

Dijkstra J and Jager CP. 1998. Practical Plant Virology: Protocols and Exercises. Springer Verlag, New York. 459p.

Fulton RW. 1970. Prune dwarf virus. CMI/AAB Description. Plant Viruses 3:23-25.

Ghanem GAM. 2000. Occurrence of prunus necrotic ringspot Ilarvirus (PNRSV) in stone fruit orchards (Plum and Peach cultivars) in Egypt. Egypt Journal of Phytopathology 28: 81-94.

Gumus M, Paylan IC, Matic S, Myrtra A, Sipahioglu HM and Erkan S. 2007. 
Occurrence and distribution of stone fruit viruses and viroids in commercial plantings of Prunus species in western Anatolia, Turkey. Journal of Plant Pathology 35: 265-268.

Hammond RW. 2011. Prunus necrotic ring spot virus. In virus and virus-like diseases of pome and stone fruits (eds.) Hadidi A, Barbra M, Candresse T and Jelkmann W. APS press, St Paul, MN, USA. pp. 207- 213.

Hammond. 2003. Phylogeny of isolates of prunus necrotic ringspot virus from the Ilarvirus Ringtest and identification of group specific features. Archives Virology 148:1195-1210.

Handa A and Bhardwaj SV. 1994. Comparative study on the use of alkaline phosphatase and penicillinase based direct antigen coating ELISA for the detection of poty virus from faba bean. FABIS 34/35: 36-38.

Kapoor S and Handa A. 2017a. Serological Evidence for the Presence of Prunus Necrotic Ring Spot Virus in Stone Fruits with Particular Reference to Peach. International Journal of Current Microbiology and Applied Sciences 6:4078-4083.

Kapoor S and Handa A. 2017b. Prevalence of PNRSV in Peach orchards of Himachal Pradesh and its detection through DASELISA. Journal of Plant Diseases Sciences 12:129-132.

Lemmetty A. 1988. Isolation and purification of apple chlorotic leaf spot virus and its occurrence in Finnish orchards. Acta Horticulturae 235: 177-180.

Mink. 1992. Ilarvirus vectors. Advances in Disease Vector Research 9: 261-290.

Myrtra A, Terlizzi BD, Boscia D, Choueiri E, Gatt M, Gawriel I, Caglayan K, Varveri C, Zerandini H, Aparici F, Pallas V and Savino V. 2001. Serological characterization of Mediterranean
PNRSV isolates. Journal of Plant Pathology 83: 45-49.

Pallas V, Aparicio F, Herranz MC, Amari K, Sanchez-Pina MA, Myrtra A and Sanchez- Navarro JA. 2012. Ilarviruses of Prunus species: A continued concern for Fruit trees. Phytopathology 102: 1108-1120.

Rageshwari S, Renukadevi P, Malathi VG, Amalabalu P and Nakkeeran A. 2017. DAC-ELISA and RT-PCR based confirmation of systemic and latent infection by Tobacco Streak Virus in cotton and parthenium. Journal of Plant Pathology 99: 444-449.

Ramiah M, Bhat AI, Jain RK, Pant RP, Ahlawat YS, Prabhakar K and Varma A. 2001. Isolation of an isometric virus causing Sunflower Necrosis Disease in India. Plant Disease 85: 443p.

Roussel S, Kummert J, Dutrecq O, Lepoivre P and Jijakli MH. 2004. Development of molecular tests for the detection of Ilar and latent viruses in fruit trees. Common Applied Biology Science 69: 427-432.

Salam AAM, Ibrahim AM. Abdelkader HS, Aly AM and El-Saghir SM. 2007. Characterization of two isolates of Prunus necrotic ringspot virus (PNRSV) from peach and apricot in Egypt. Arab Journal of Biotechnology 11:107-112.

Salem N, Mansour A, Al-Musa A and AlNsour A. 2003. Incidence of Prunus necrotic ringspot virus in Jordan. Phytopathologia Mediterranea 42: 275279.

Salem N, Mansour A, Almusa A, Nsour A and Hammond R. 2004. Identification and partial characterization of prunus necrotic ring spot virus on stone fruits in Jordan. Journal of Plant Pathology 86: 85-90.

Scott SW. 2014. Viruses of peach. http://www.clemson.edu/extension/peac 
h/commercial/ diseases/files/h7.5.pdf [10:10AM, 12th March 2018]

Sujitha A, Bhaskara RBV, Sivaprasad Y and Usha R. 2015. Partial characterization of replicase gene of Tobacco Streak Ilarvirus in onion (Allium cepa L.). International Journal of Applied Biology and Pharmaceutical Technology 6: 155-160.

Szyndel MS, Sala-Rejczak K and PaduchCichal E. 2006. Serological relationships among prunus necrotic ringspot virus (PNRSV) isolates from stone fruit trees, rose and hop plants recognized by ISEM + Decoration Technique. Phytopathology 40: 31-41.

Vemulapati B, Drufflel KL, Husebye D, Eigenbrode SD and Pappu HR. 2014. Development and application of ELISA assays for the detection of two members of the family Luteoviridae infecting legumes legumes: Pea enation mosaic virus (genus Enamovirus) and Bean leaf roll virus (genus Luteovirus). Annals of Applied Biology 165: 130-136.

Virscerk M and Mavric I. 2005. Factors affecting the reliability of PDV and PNRSV detection in peach by DASELISA. Die Bodenkultur 5: 47-52.

Wells JM, Krikpatrick HC and Parish CL. 1986. Symptomatology and incidence of prunus necrotic ringspot virus in peach orchards in Georgia. Plant Disease 70: 444-447.

Winkowska L, Grimova L and Rysanek P. 2016. Occurrence of several viruses infecting wild growing stone fruit trees in Central Bohemia. Plant Sciences 47: 141-147.

\section{How to cite this article:}

Shelly Kapoor and Anil Handa. 2018. Correlating Field Symptoms of PNRSV with DAC and DAS-ELISA based Serological Detection. Int.J.Curr.Microbiol.App.Sci. 7(08): 4705-4717. doi: https://doi.org/10.20546/ijcmas.2018.708.495 